\title{
呼吸抵抗測定による他覚的嗅覚検査
}

\author{
東邦大学医学部付属大橋病院耳鼻咽喉科学研究室（主任：臼井信郎教授） \\ 星野忠彦, 白 井信郎 \\ 大阪赤十字病院耳鼻咽喉科 \\ 仁瓶 誠 吾

\section{OBJECTIVE OLFACTOMETRY BY THE METHOD OF RECORDINGS OF RESPIRATORY RESISTANCES}

TADAHIKO HOSHINO, M. D. and NOBUO USUI, M. D.

Department of Otorhinolaryngology, Ohashi Hospital, Toho University School of Medicine, Tokyo

SEIGO NIHEI, M. D.

Department of Otorhinolaryngology, Osaka Red Cross Hospital, Osaka

Respiratory resistances (Rrs) through nose and mouth in response to inhalation of iso-vareric acid were recorded by means of forced pressure and flow oscillations $(3 \mathrm{~Hz})$ superimposed on spontaneous breathing. Subjects without nasal diseases and olfactory disturbances, and laryngectomized patients were obliged to breathe at a constant pattern, and not to stop breathing during recording of Rrs.

1) Inspite of whether the nasal membrane except for the olfactory region was local-anesthetized or not, Rrs through nose and mouth were significantly increased at $1 \%$ level in response to nasal inhalation of the odor, which probably stimulated both olfactory and trigeminal nerves.

2) The increase of Rrs through nose in response to the nasal inhalation did not significantly differ from that through mouth in response to the same stimulation at $5 \%$ level.

3) The effect of oral inhalation of the odor on Rrs through mouth was a little if present.

4) In laryngectomized, Rrs below the stoma were significantly increased in response to the odorant stimulation through nose at $5 \%$ level.

These results suggest that the increase of Rrs through nose seems to be attributed mainly to the increase of Rrs below mouth, especially below trachea and that the recordings of Rrs in response to olfactory stimulation is useful in objective olfactometry. And olfacto-pulmonary reflex is discussed in this paper.

Key words: 呼吸抵抗測定, 他覚的嗅覚検查, 嗅賞一肺反射

$\mathrm{A} 90-0516-30522$

1. 緒 言

従来より嗅覚が残存するか否かを他賞的・客観的に 評価することは交通事故後の補償問題も含めて社会問
題上，しばしば必要とされてきた。その測定法として 呼吸反応, 瞳孔反射, 脑波, $\mathrm{EOG}, \mathrm{CNV}$ 等が利用さ

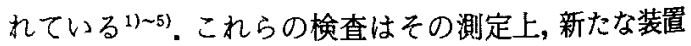


が必要であるため，広く普及されていない。その実用 化にあたっては，測定方法が簡単なこと，正常者にお ける陽性率が高いことが重要であるが，既存の測定機 器て代用されれば，更に普及されると考えられる，今 回我々は耳鼻咽喉科領域でも広く普及されつつある鼻 腔通気度計の 1 つを用いて, 咱刺激の際の呼吸抵抗を 測定し，この反応が嗅覚検査に応用できるかどうかを 検討した.さらに, 嗅神経一肺反射の存在の可能性に ついて考察した.

\section{2. 研究対象及び方法}

対象仗鼻疾㭧がない嗅覚正常者, 成人 21 名之喉頭摘 出後 1 年以上 4 年以内を経た 6 名である. Chest 社製 Rhinograph (TUC-5600 M 型)による $3 \mathrm{~Hz}$ Oscillation 法にて鼻及び口呼吸抵抗を測定した。本装置によ る呼吸抵抗測定の原理は滝島到によって述べられてお り，その臨床応用についても十分考察されている778). それぞれの抵抗は本装置付属のアナログ演算回路によ り 1 秒間に 3 回の割合で自動的に計測され $\mathrm{X}-\mathrm{Y}$ recorder 上に描記された. 求められる抵抗は粘性抵抗 である。嗅刺激には T\&T オルファクトメーターの C5(iso-vareric acid)を用いた。搝刺激装置は原理的 には梅田等の嗅刺激装置III型?を参考にし嗅刺激の際 に開閉する電磁弁の音を出来るかぎり小さくした，刺

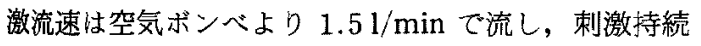
時間は 1 分間である.この流速で空気のみをマスク内， マウスピース内へ送気しても鼻及びロ呼吸抵抗の変化 はすべての症例で起こらなかった。さらに空気のみを 1 分間不規則に挿入することにより咱刺激の開始と終 了を被検者に予見しにくくした。

(実験 (1))

マスクにて鼻呼吸抵抗を測定し，基線が安定した状 態で，マスク内へ，注射針を介してC5を送気した。 測定前・中・後とも被検者に呼吸パターンを変更させ ないように指示し，鼻呼吸を継続させた。

(実験 (2))

次に被強者にマウスピースをくわえさせ，口呼吸抵 抗を測りながらマウスピース内へ(1)と同様に刺激を行 った。鼻呼吸ができないように鼻入口部をノーズクリ ップにて塞いだ.

(実騟 (3))

被検者の口呼吸抵抗を測りながら，一側鼻腔へ，， スルを介して，(1)と同様に刺激を行った。(1)〜(3)の赛 験について 7 名は鼻粘膜を無麻酔で,他の 14 名は嗅裂
部を除く両側鼻粘膜を広範囲に $4 \%$ \%キシロカインで麻 酔して実験を行った，同一被検者について，(1)，(2)， (3)の実験の間には少なくとも 30 分間の wash out 期 間を設けた。

(実験 (4))

喉摘者 6 名につき気切孔よりカフ付カニューレを介 して呼吸抵抗を計り，無麻酔下(3)と同様の刺激を行っ た.

(1)，(3)，(4)の実験で，刺激により全例強い㖵覚を生じ た.

\section{3. 結 果}

コントロールの值は刺激開始前, 十分基線が安定し た時点における 1 分間の呼吸抵抗の平均 (Rrs. cont) であらわした，刺激による抵抗増加は刺激開始後 1 分 以内にみられ，コントロールとの比較にはその抵抗の 最大值 (Rrs. max) 用いた。図 1, 2 は無麻酔群, 麻 酔群症例の実験(1)，(2)，(3)での刺激に対する呼吸抵抗 の変化を示したものである，表 1 は全症例のRrs. cont, Rrs. max 及び 2 者の抵抗差 (Rrs. max-Rrs. cont $=$ Rrs. dif）の平均と標準偏差を示したものであ る. 以下データーの統計解析は Snedecor ${ }^{\text {() }}$, 緒方 ${ }^{(0)} に$ 従って行った。

1. 正常嗅覚者 21 名についての分散分析及び多重比 較

$21(\mathrm{n})$ 人の症例をランダムに $7\left(\mathrm{n}_{1}\right)$ 人と $14\left(\mathrm{n}_{2}\right)$ 人 に分け，一方を無麻酔下で，他方を麻酔下で実験を行 っている。 i 群(無麻酔群か麻酔群のどちらか, $\mathrm{i}=1,2$ ) の $\mathrm{j}$ 実験 (実験(1)，(2)，(3)， j=1，2，3)の $\mathrm{k}$ 番目の症 例 $\left(\mathrm{k}=1,2, \cdots \cdots \mathrm{n}_{1}+\mathrm{n}_{2}\right)$ の抵抗差を yijk とすると, $\mathrm{yijk}=\mu+\alpha \mathrm{i}+\rho \mathrm{ik}+\beta \mathrm{j}+(\alpha \beta) \mathrm{ij}+\mathrm{eijk}$

なるモデルが仮定できる、ここで， $\mu=$ 全体にわたっての平均的効果 $\alpha \mathrm{i}=\mathrm{i}$ 群に対応する主効果 $\left(\mathrm{i}=1,2, \alpha_{1}+\alpha_{2}=0\right)$ $\beta \mathrm{j}=\mathrm{j}$ 番目の実験に対する主効果 $\left(\mathrm{j}=1,2,3, \beta_{1}+\right.$ $\left.\beta_{2}+\beta_{3}=0\right)$

$(\alpha \beta) \mathrm{ij}=\mathrm{i}$ 群と $\mathrm{j}$ 群に対応する交互作用効果 $\rho \mathrm{ik}=\mathrm{i}$ 群における $\mathrm{k}$ 番目の症例に対応するランダ 厶効果

$e i j p=i$ 群の $\mathrm{k}$ 番目の症例での $\mathrm{j}$ 実験に対応するラ ンダム効果

であり分割法（split-plot design）のモデルとなってい る.このモデルのもとで, 分散分析を行った、結果を 表 2 に示す.この結果から次のことが言える. 
$\mathrm{cm} \mathrm{H}_{2} \mathrm{O} / L$ PS

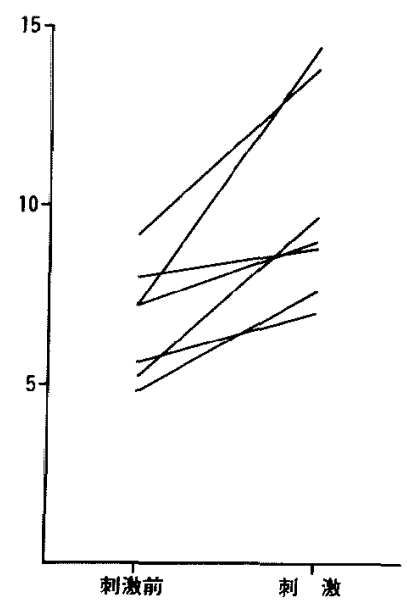

$\mathrm{cm} \mathrm{H}_{2} \mathrm{O} / \mathrm{L}$ PS

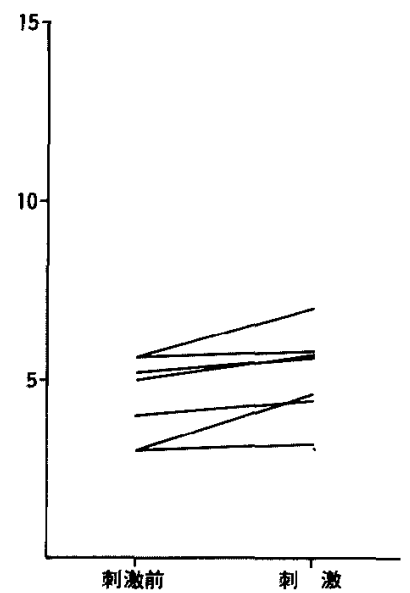

$\mathrm{Cm} \mathrm{H}_{2} \mathrm{O} / \mathrm{L}$ PS

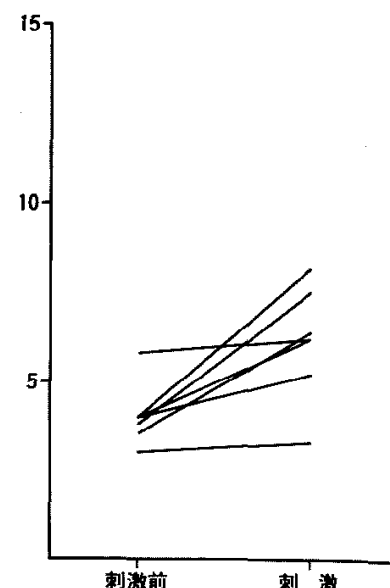

図 1 無麻酔群 $(\mathrm{n}=7)$

左より奏験(1)，(2)，(3)の刺激前呼吸抵抗(Rrs. cont) と刺激時呼吸抵抗最大值(Rrs. max)

$\mathrm{cm} \mathrm{H}_{2} \mathrm{O} / \mathrm{L}$. PS

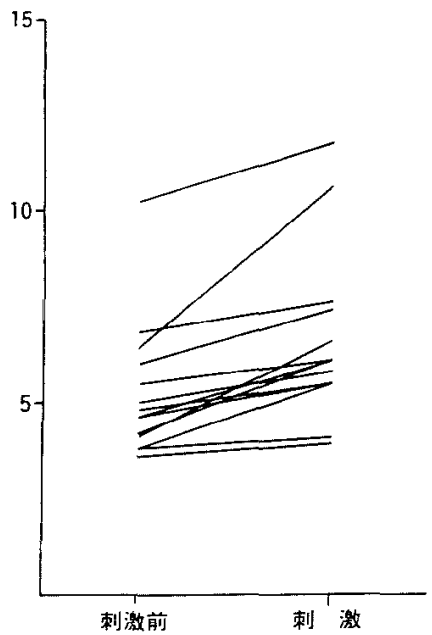

$\mathrm{cm} \mathrm{H}_{2} \mathrm{O} / \mathrm{LPS}$

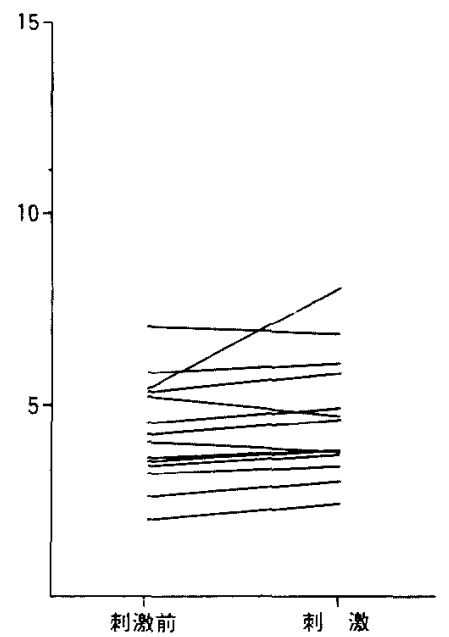

$\mathrm{Cm} \mathrm{H}_{2} \mathrm{O} / \mathrm{L}$ PS

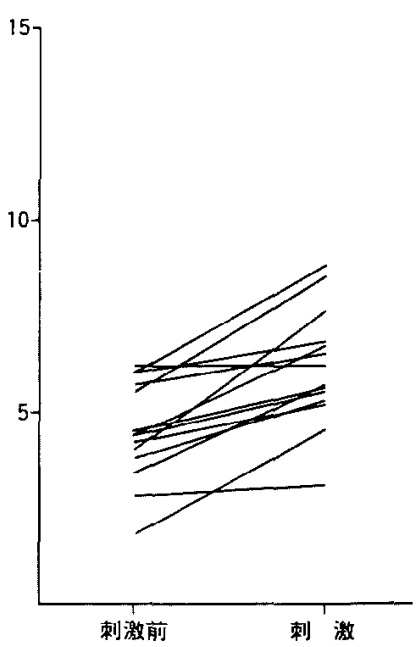

図 2 麻酔群 $(\mathrm{n}=14)$

左より実験(1)，(2)，(3)の刺激前呼吸抵抗(Rrs. cont) と刺激時呼吸抵抗最大值(Rrs. max)

I . 無麻酔と麻酔群では平均的に抵抗差が異なる $(\mathrm{P}<0.01)$.

II . 無麻酔, 麻酔を考慮せず実験(1)(2)(3)において平均 的な抵抗差が異なる $(\mathrm{P}<0.01)$.

III. 無麻酔か麻酔かに上って奏験(1)(2)(3)の平均的傾 向は変わらない $(\mathrm{P}>0.05)$.

実験間が有意であるので個々の実験の間の差について Scheffe の方法に從って多重比較を行った。この場合
刘応する平方和に対する棄却值は

$$
\mathrm{Ve}_{2} \times 2 \times \mathrm{F}\left(2,2\left(\mathrm{n}_{1}-1\right)+2\left(\mathrm{n}_{2}-1\right) ; \alpha\right)
$$

である $\left(\mathrm{n}_{1}=7, \mathrm{n}_{2}=14\right)$.

$\mathrm{S} \ell \mathrm{m}=$ Rrs. dif. $\ell-$ Rrs. dif. $\mathrm{m}^{k}(\ell=1,2, \mathrm{~m}=2,3$, $\ell \neq \mathrm{m}$ ，実験(1)，(2)，(3)に対応する) と定義し

$\mathrm{S} \ell \mathrm{m}>\mathrm{Ve}_{2} \times 2 \times \mathrm{F}\left(2,2\left(\mathrm{n}_{1}-1\right)+2\left(\mathrm{n}_{2}-1\right) ; \alpha\right)$

であれば個々の奏験間の抵抗差には平均的に有意の差 があると言える。棄却值はおよそ 
表 1 各呼吸抵抗の平均と標準偏差

各実験ごとの症例のRrs. cont, Rrs. max, Rrs. difの平均と標準偏差.

単位: $\mathrm{cm} \mathrm{H}_{2} \mathrm{O} / \ell / \mathrm{sec}$

\begin{tabular}{|c|c|c|c|c|c|}
\hline \multirow{4}{*}{\multicolumn{2}{|c|}{$\begin{array}{l}\text { 実験 } \\
\text { (無麻醉群) }\end{array}$}} & & Rrs.cont & Rrs. max & Rrs. dif (Rrs.max-Rrs.cont) \\
\hline \multirow{3}{*}{$\begin{array}{l}\text { 実 } \\
\text { （無麻西 }\end{array}$} & & (1) & $6.74 \pm 1.61$ & $10.00 \pm 2.92$ & $3.36 \pm 2.25$ \\
\hline & & (D) & $4.49 \pm 1.15$ & $5.19 \pm 1.23$ & $0.71 \pm 0.60$ \\
\hline & & (3) & $4.01 \pm 0.87$ & $6.14 \pm 1.59$ & $2.13 \pm 2.13$ \\
\hline \multirow{3}{*}{$\begin{array}{l}\text { 実 } \\
\text { (麻 醉 }\end{array}$} & \multirow{3}{*}{ 験 } & (1) & $5.24 \pm 1.74$ & $6.61 \pm 2.19$ & $1.36 \pm 1.03$ \\
\hline & & (2) & $4.33 \pm 1.44$ & $4.70 \pm 1.64$ & $0.36 \pm 0.71$ \\
\hline & & (3) & $4.48 \pm 1.30$ & $6.14 \pm 1.52$ & $1.61 \pm 1.10$ \\
\hline 喉 摘 & 者 & (1) & $4.21 \pm 1.98$ & $6.17 \pm 2.53$ & $1.92 \pm 1.25$ \\
\hline
\end{tabular}

表 2 分散分析表

\begin{tabular}{|c|c|c|c|c|c|c|}
\hline \multicolumn{3}{|c|}{ (要 因) } & (平方 和) & (自由度) & ( 平均平方) & $\left(F_{o}\right)$ \\
\hline 群 & & 間 & $\begin{array}{r}12.762 \\
(S G)\end{array}$ & 1 & $\begin{array}{c}12,762 \\
(V G)\end{array}$ & $\begin{array}{l}8.826^{* *} \\
\left(V_{S} / v_{2}\right)\end{array}$ \\
\hline 群 & 内 & $\curlywedge\left(e_{4}\right)$ & $\begin{array}{r}27.471 \\
\left(\mathrm{Se}_{1}\right)\end{array}$ & $\begin{array}{c}19 \\
\left(n_{1}-1\right)+\left(n_{2}-1\right)\end{array}$ & $\begin{array}{l}1,446 \\
\left(V e_{1}\right)\end{array}$ & $\left(\mathrm{ve}_{1} / v_{\mathrm{e}_{2}}\right)$ \\
\hline 害 & 駼 & 間 & $\begin{array}{c}29.025 \\
\left(S_{E \times P}\right)\end{array}$ & 2 & $\begin{array}{c}14,5125 \\
\left(V_{E \times P}\right)\end{array}$ & $\begin{array}{c}9.879^{\prime \prime} \\
\left(\mathrm{VE} \times \mathrm{P} / \mathrm{Ve}_{2}\right)\end{array}$ \\
\hline 実 & $x$ & 群 & $\begin{array}{r}7,612 \\
(S E \times P \times G)\end{array}$ & 2 & $\begin{array}{c}3,806 \\
(V E \times P \times G)\end{array}$ & $\begin{array}{c}2,591 \\
\left(V_{E \times P \times G / V e_{2}}\right)\end{array}$ \\
\hline 残 & & 差 $\left(\mathrm{e}_{2}\right)$ & $\begin{array}{r}55,823 \\
\left(\mathrm{Se}_{2}\right)\end{array}$ & $\begin{array}{c}38 \\
2\left(n_{1}-1\right)+2\left(n_{2}-1\right)\end{array}$ & $\begin{array}{l}1,469 \\
\left(V_{2}\right)\end{array}$ & \\
\hline 生 & & 体 & $\begin{array}{r}132.693 \\
\left(S_{T}\right)\end{array}$ & $\begin{array}{c}62 \\
3\left(n_{1}+n_{2}\right)-1\end{array}$ & & \\
\hline & $F(1$ & 1. $19 ; 0$. & $=8.18$ & & $F(1.19,0.05)=4.38$ & \\
\hline & $F(2$ & $2.40 ; 0$. & $=5.18$ & & $F(2.40,0.05)=3.25$ & \\
\hline & $*$ & $1 \%$ の危 & で有 & & $5 \%$ の危険率で有 & \\
\hline
\end{tabular}

$\mathrm{Ve}_{2} \times 2 \times \mathrm{F}(2,40 ; 0.05)=9.490$

$\mathrm{Ve}_{2} \times 2 \times \mathrm{F}(2,40 ; 0.01)=15.219$

となる。

$$
\begin{aligned}
& \mathrm{S}_{12}=26.398 \\
& \mathrm{~S}_{13}=0.644 \\
& \mathrm{~S}_{23}=17.745
\end{aligned}
$$

となり実験(1)と(3)の平均的な抵抗差には差があると言 えないが実験(2)は実験(1)と(3)と平均的な抵抗差におい

て違いがあると言える(これは無麻醉，麻酔にかかわ らず言える)。

II. 喉摘者の抵抗変化について

搌摘者 6 名について Rrs. cont と Rrs. max を図 3
に示した. Rrs. cont と Rrs. max に関して対応のある 平均值の差の検定を行ったが， to $=3.939$ であり $5 \%$ 危険率 $(\mathrm{t}(5,0.05)=2.571, \mathrm{t}(5,0.01)=4.302)$ で刺 激によって抵抗が有意に上昇したと言えた。さらに無 麻轱群鼻刺激時の口呼吸抵抗と喉摘者鼻刺激, 気管孔 以下の呼吸抵抗増加の比較を行ったところ, 平均值の 差の検定では $5 \%$ \%危検率で有意差を認めなかった (図 4).

\section{4. 考察}

におい刺激に対する呼吸系の反応については古くか ら調べられている. Kratschmer ${ }^{13}$ は夕バコの煙,アン 
Cm $\mathrm{H}_{2} \mathrm{O} / \mathrm{LPS}$

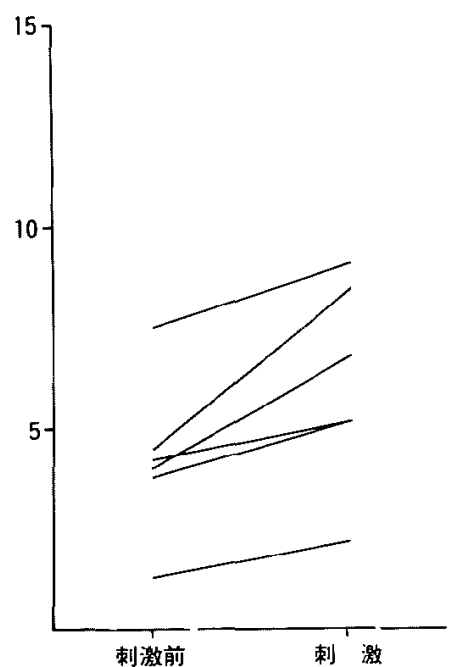

図 3 喉摘者 $(n=6)$ の嗅賞刺激に対する刺激 前呼吸抵抗(Rrs.cont) と刺激時㭔吸抵 抗最大值 (Rrs. max)

モニア，酢酸の家息鼻腔への刺激で無呼吸，喉頭閉鎖 や心拍数の減少を認めたが，この反射は三叉神経を経 て生ずるものと考えられだ112). 一方 Allen ${ }^{13)}$ はこの ような反射が嗅覚系及び三叉神経系双方の刺激で起こ ると報告しVon Skramlik ${ }^{14)}$ は嗅球の電気刺激で啨吸 リズムの変化が生じることを観察した。さらに Mcritchie ${ }^{15)}$ らは，嗅神経がこのような㪀射に直接関与 せず三叉神経の刺激によって起こる反射を増強するに 過ぎないと報告している，いずれにしても㖵神経刺激 による呼吸反射は, Angel James ${ }^{16)}$ 等により動物で確 められた三叉神経剌激による呼吸循環反射ほどには実 証されていないのが現状である。一般に悪臭が進入し た時には，呼吸系はそれらの進入を出来るだけ防ぎ， あるいは排除する方向に努めると考えるのは妾当であ る、本研究においては，以上の点を考慮し麻酔群と無 麻酔群に分けて実験を行った。また実験を補足する意 味で喉摘者 6 名についても実験を行った。無麻酔群と 麻酔群では平均的に抵抗差が異なり，無麻酔群は麻酔 群に比べてより大きな抵抗差が生じた。しかしその刺 激による抵抗の上昇の仕方の傾向は変わらなかった。 このことはC5の送気が咱神経だけでなく三叉神経を も刺激している可能性を示している.すなわち本実験 を臨床に応用するためには嗅裂部を除く鼻腔を広範囲 に麻酔する必要がある。㬋頭以下にも科学的刺激に応

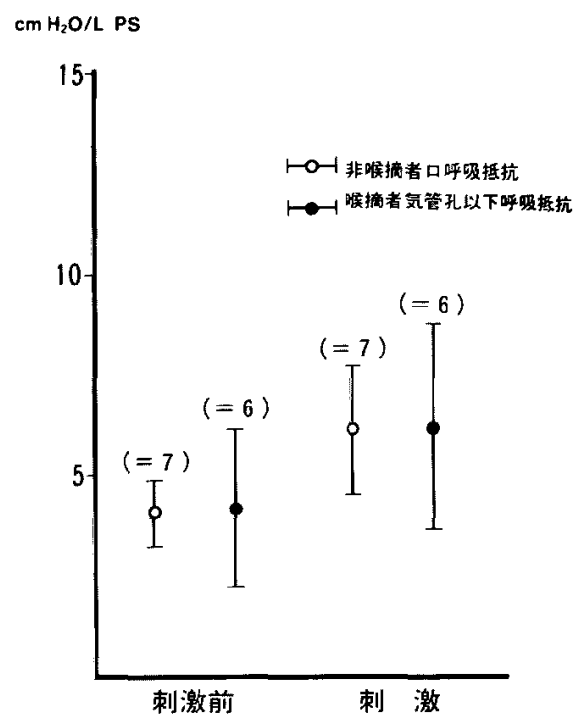

図 4 無麻酔群鼻刺激口呼吸抵抗と啹摘者 鼻刺激気管孔以下呼吸抵抗の比較 それぞれの呼吸抵抗の平均と標準偏差 を示す。

答する知覚神経線維の存在が知られている ${ }^{17) 18,199201}$. またこれらの刺澈によって呼吸反射が生じるとされて いる.しかし実験(2)に扔ける抵抗増加は(1)，(3)に比べ て有意に低く明らかでなかった。つまり今回の実験状 態では嗅素はほとんど鼻腔で捕えられるか，口以下の 気道に進入しても著しい呼吸抵抗増加を引き起こさな いと考えられた。実験(1)と(3)の抵抗差に有意差を認め なかったこと，さらに喉摘者において刺激により気切 孔以下の呼吸抵抗増加が認められたことは，その反応 の主体が気管以下の気道であることを示しているかも しれない。(1)，(2)，(3)の実験において，意識的に声帯 を闒じることによっても抵抗増加が生じる，しかし被 検者全例は呼吸継続と呼吸パターンの維持が義務づけ られている。たとえ声帯閉鎖があったとしても急激な 呼吸抵抗の上昇からその check は容易である，本実験 ではそのような急激な呼吸抵抗增加は認められていな い.さらに無麻酔群鼻刺激時の呼吸抵抗の増加と喉摘 者䩿刺激時の気管孔以下の呼吸抵抗増加の間に有意な 差が認められなかったことから本実験においては喉頭 に関する抵抗増加はあまり考慮されなかった。また臨 床応用においては，刺激と急激な呼吸抵抗の堌加が同 時に起これば，それ自体が診断のための一助となりう るであらう。

本実験で計算される呼吸抵抗の增加が気道の収縮だ 
けを意味するものでなく，肺組織や胸郭組織の粘性抵 抗の増加を多少含む可能性も否定できない.しかし， 刺激による複雑な呼吸反応を量的，総合的に評価する 意味で, 本検査は有用と考えられる.すなわち臨床検 查への応用として本検查は刺激による一瞬の声帯閉鎖 も含めて，様々な呼吸反応を捉える可能性があり，そ れを数值化する。黑石引は呼吸曲線による反応を用い た嗅覚検查を報告し， T\&T オルファクトメーターの 㭘知閥値と反応闇值について調べた。本検查において もこの点について更に検討する必要がある。しかし現 時点においても脱失か否かを判明するには十分有用て あると考元られる。今般鼻腔通気度検查は広く臨床に 普及され始めている，またその測定器も国内外で数社 から発売されるに至っている. 本来は鼻閉の客観的障 害の評価, 耳鼻咽喉科領域の換気機能検查の一環とし て使用されてきた ${ }^{21)}$. 本実験における検査器械の使用 方法は，その本来の目的における臨床への普及化とと もに，非常に利用しやすく，検查器械の有用性を高め ると考えられる。またその使用方法は測定器械自体の 改良による簡便さにより特別な手技を必要としない. 実際の嗅覚測定に際しては前述したように麻醉下での (1)の実験方法が最良と考えられる，鼻腔への直接送気 は，嗅素が無くても三叉神経を刺激する可能性があ $\eta^{22)}$ ，一方本実験におけるマスク内への嗅素の送気は 直接鼻腔へ入らず，ほとんど認知することの不可能な $3 \mathrm{~Hz}$ の正弦波振動に乗って流入するので麻酔下, 実験 (1)の方法では被検者はただマスクにて鼻呼吸をするだ けで良い。またその際の抵抗上昇は表 1 より口以下の 嗅素の刺激等を除外するため $1 \mathrm{cmH}_{2} \mathrm{O} / \mathrm{l} / \mathrm{s}$ 以上を陽 性とするのが妥当と考える。

以上，に扔い刺激による呼吸抵抗の変化を測定し， 嗅覚障害の他覚的・客観的検査法としての利用を考え た。

\section{5. 結 論}

Rhinograph $3 \mathrm{~Hz}$ Oscillation 法による呼吸抵抗測 定が他党的嗅覚検查法として応用可能か否かを榆討し た. 嗅素は $\mathrm{T} \& \mathrm{~T}$ オルファクトメーターの C 5(isovareric acid）を使用した，対象は鼻疾患，嗅覚障害の 無认健常成人（21名）と喉摘者（6名）である。被㭘 者には測定期間中, 呼吸の継続及びパターンの変更禁 止を義務づけた。

1) 嗅覚刺激による鼻及び口呼吸抵抗の増加が全例に 認められた。この増加は嗅神経及び三叉神経双方の刺
激により起こると考えられた。

2）鼻呼吸抵抗増加は主に口以下の呼吸抵抗の增加に よるものであり，喉摘者による実験で，さらにその反 応の主体が気管以下の気道であることが推定された。

3）嗅素の口以下の気道への刺激反応はあっても軽微 であると考えられた。

以上から嗅刺激に対する呼吸反射について検討を加 え，呼吸抵抗測定が嗅覚の他賞的・客観的評価のため に十分有用であると結論した。

\section{参考文献}

1）豈田文一，北村武，高木貞敬編：嗅覚障害 その測 定と治療. 医学書院，東京 1978，81-91 頁.

2）梅田良三：嗅覚障害の診断と治療をめぐって。第 82 回日耳鼻総会宿題報告集, 京都, 1981，37-67 頁.

3) 西田裕明 他：嗅刺激による瞳孔反射一客観的嗅覚 検査法としての実用化について。昍鼻 $76: 1449$ $-1458,1973$.

4）鈴木秀明：CNV を指標とした他覚的㖵覚検査法. 日耳鼻 $87: 1-15,1984$.

5) 黒石敏弘：呼吸曲線を指標とした客観的嗅覚検查. 日耳鼻 $84: 390-399,1981$.

6) 滝島 任他：気道過敏性検出のための新しい試み. 日本医事新報 $2797: 30-34 ， 1977$.

7) 鉿木俊介他：運動負荷試験における呼吸抵抗の連 続測定。呼と循 29:29-38，1981.

8）臼井信郎 他：ライノグラフによる定量的鼻誘発試 験。日耳鼻 $87: 160-168,1984$.

9) Snedecor GW, Cochran WG : Statistical Methods, 6th edition, Iowa State University press, Ames, 1967.

10）緒方正名 他：医学統計法, 同文書院, 東京, 1983.

11) Kratschmer F : Uber Reflex von der Nasensch leimhaut auf Athmung und Kreislauf. Sitzber. Akad. Wien, 62 : 147-170,1870.

12) Anderson $P$ : Inhibitory reflexes elicited from the trigeminal and olfactory nerves in rabbits. Acta Physiol Scan 30 : 137-148, 1954.

13) Allen WF : Effects on respiration, blood pressure and carotid pulse of various inhalated and insufflated vapors when stimulating one cranial verve and various combinations of cranial nerves. Am J Physiol 88: 117-129,1929.

14) Von Skramlik E : Die Physiologie des Luftwegs. Hnbk Norm Pathol Physiol Atmung. 'Springer- 
Verlag, Berlin, 1925, pp. 128-189.

15) Mcritchie RJ and white $S W$ : Role of trigeminal, olfactory, carotid sinus and aortic nerves in the respiratory and circulatory response to nasal inhalation of cigarette smoke and other iritants in the rabbit. Aust J Exp Biol Med Sci 52 : 127140,1974 .

16) Angell James JE and Daly MDEB : Reflex respiratory and cardiovascular effects of stimulation of receptors in the nose of the dog. J Physiol 220 : 673-696, 1972.

17) Szereda-Przestaszewska, $M$ and Widdicombe JG : Reflex of chemical irritation of the laryngeal lumen in cats. Resp Physiol 18: 107-115, 1973.

18) Bickerman HA et al : Cough response of healthy human subjects stimulated by citric acid aerosol, II, Evaluation of antitussive agents. Am J Med Sci 224 : 191-206, 1957.

19) Widdicombe JG : Respiratory reflexes from the trachea and bronchi of the cat.

J Physiol 123 : 55-70,1954 (a).

20) Widdicombe JG : Receptors in the trachea and bronchi of the cat. J Physiol 123 : 71-104,1954(b).

21） 戸川 清：鼻呼吸障害一その病態生理と臨床一. 第 28 回日耳鼻総会宿題報告集, 盛岡, 1982 .

22) Tucker D:Olfactory, vomeronasal and trigeminal receptor responses to odorants, in Zotterman Y (ed) : Olfaction and Taste, Vol. 1. New York, Pergamon Press, 1963, pp. 45-69.

本論文の要旨は 1982 年 5 月, 第 83 回日本耳鼻咽喉科学 会総会にて発表した。

（原稿受付 昭和 61.4.11日）

別刷請求先 $\bar{\top} 153$ 東京都目黑区大橋 2-17-6 東邦大学医学部大橋病院耳鼻咽啹科 星野忠彦 